Available online on 15.06.2020 at http://jddtonline.info
Open Access to Pharmaceutical and Medical Research
unrestricted non-commercial use, provided the original work is properly cited

Open $\odot$ Access

Research Article

\title{
In-Vitro Antibacterial Activity of Endophytic Fungi from Peganum harmala L. (Laghouat, Algeria)
}

\author{
Yasmina Ouzid ${ }^{1}$ 2*, Siliya Karaoui², Noria Smail Saadoun ${ }^{2}$, Karim Houali ${ }^{3}$ \\ ${ }^{1}$ Faculty of sciences, Department of Biology, M'hamed Bougara University, Boumerdes, 35000, Algeria \\ 2 Laboratoire Resources Naturelles (LRN). Department of Agronomy, Faculty of Biological Sciences and Agronomic Sciences. Mouloud Mammeri \\ University, Tizi-Ouzou, 15000, Algeria \\ ${ }^{3}$ Laboratory of analytic biochemistry and biotechnology (LABAB). Department of Biochemistry and Microbiology, Faculty of Biological Sciences \\ and Agronomic Sciences. Mouloud Mammeri University, Tizi-Ouzou, 15000, Algeria
}

\begin{abstract}
Medicinal plants are an inexhaustible source of molecules. They are colonized by mycoendophytes, fungi living in their tissues without apparent symptoms. These fungi can provide secondary metabolites with biological activities. It is with this in mind that we are interested in a spontaneous plant from the dayas region (Laghouat, Algeria): Peganum harmala or Harmel, a toxic medicinal plant belonging to the family Zygophyllaceae. Our study consists in highlighting the antibacterial activity of four kinds of mycoendophytes: Cladosporium, Alternaria, Aspergillus and Penicillium isolated from the leaves of this plant. The antibacterial activity is evaluated by the technique of the double disk diffusion on agar with respect to some Gram-positive bacterial strains. We have adopted two protocols for this purpose. For the first, the mycelia of all the mushrooms are deposited in the same petri dish. For the second, a single disc of the mycelium of a single species is deposited per box. The results obtained show a difference in the sensitivity of the bacterial strains to the bioactive substances of the mycoendophytes studied. The Alternaria genus showed the most significant activity. ANOVA performed between the mean diameters of the mycoendophyte inhibition zones and the antibiotic test disc: Chloramphenicol showed a highly significant difference between these two measurements. The Newman-Keuls test revealed a difference in the susceptibility of bacterial strains to the secondary metabolites of fungus mycoendophytes of Peganum harmala according to the two protocols used. The antibacterial effect is related to interactions between endophytic fungi and their host plant.
\end{abstract}

Keywords: mycoendophytes, antibacterial activity, interactions, Peganum harmala L., Laghouat (Algeria), endophytic fungi and their host plant.

Article Info: Received 22 March 2020; Review Completed 19 May 2020; Accepted 25 May 2020; Available online 15 June 2020

Cite this article as:

Ouzid Y, Karaoui S, Smail Saadoun N, Houali K, In-Vitro Antibacterial Activity of Endophytic Fungi from Peganum harmala L. (Laghouat, Algeria), Journal of Drug Delivery and Therapeutics. 2020; 10(3-s):47-51

http://dx.doi.org/10.22270/jddt.v10i3-s.4149

口. *Address for Correspondence:

Yasmina Ouzid, Faculty of sciences, Department of Biology, M'hamed Bougara University, Boumerdes, 35000, Algeria

\section{INTRODUCTION}

Medicinal plants like most plants are related to endophytic microorganisms that they harbor within their tissues (Strobel et al., 2002 ; Ellouz, 2011). Bacteria and microscopic fungi represent these endophytes (Schulz et al., 2006). They are an important component of the plant community (Arnold et al., 2001; Arnold et al., 2003) and can develop with it various interactions. Mycoendophytes can contribute to plant growth and defence and are an important source of bioactive metabolites with potential applications in agriculture, medicine and the food industry. During the last two decades, many compounds have been isolated from these endophytic fungi with various biological activities such as antimicrobial, anticancer, cytotoxic and insecticidal (Schulz et al., 2002 ; Zhao et al., 2010). In the present study, we were interested in a medicinal plant from the arid regions of Algeria: Peganum harmala (Harmel), a plant of the family Zygophyllaceae. It is a cosmopolitan species that grows spontaneously in semi-arid regions, steppes and sandy and saline soils (Darabpour et al., 2011 ; Hammiche et al., 2013 ; Niroumand et al., 2015). Our objective is to evaluate the antibacterial activity of fungus mycoendophytes of Peganum harmala of dayate Aiat (Laghouat, Algeria) by the technique of double diffusion on agar. 


\section{METHODS}

\section{Mycelia of fungus mycoendophytes of Peganum harmala}

Four genera of mycoendophytes Cladosporium, Alternaria, Aspergillus and Penicillium were selected, identified and purified from the leaves of Peganum harmala, harvested in the arid Laghouat region, at dayate Aiat in April 2015. Mycelia of fungus mycoendophytes are incubated for 8 days at room temperature.

\section{Bacterial material}

The Laboratory of Analytical Biochemistry and Biotechnologies of the University Mouloud Mammeri (TiziOuzou) provided the ATCC bacterial strains. They are Enterococcus faecalis (ATCC 49452), Staphylococcus aureus (ATCC 25923), Staphylococcus aureus (FRI 326), Staphylococcus aureus (FRI S6), Staphylococcus aureus (FRI 361), Staphylococcus aureus (ATCC 43300), Staphylococcus aureus (MU 50 mecA), Staphylococcus aureus (FRI 137), Bacillus cereus (ATCC 10876), Bacillus cereus (ATCC 14579).

\section{Double diffusion technique on agar}

We used the technique described by Mandeel et al. (1998), Devaraju, and Satish (2011). The bacterial strains are revived by culture in BHI medium at $37^{\circ} \mathrm{C}$. for $18 \mathrm{~h}$ before being used. The experiment is repeated three times and the diameters of the inhibition zones are measured in millimeters. The results are expressed as mean \pm standard deviation and measurements. During the first screaning, the discs of the four mycoendophytes were placed together in each dish inoculated with the bacterial strains, as well as the antibiotic disc. In addition, each mycoendophyte disc was placed alone in a Petri dish during the second screening.

\section{Statistical analysis}

An ANOVA statistical analysis using the Stat Box 6.40 software was carried out in order to highlight the differences between the measured inhibition zones of the different mycoendophytes with respect to each of the bacterial strains. The differences between the antibacterial activities of the four endophytic fungi, but also between them and the antibiotic used, are considered statistically significant when the value of $\mathrm{p} \leq 0.05$. As a result, a complementary test of multiple mean comparisons (Newman-Keuls) is performed to classify the fungi into homogeneous groups.

\section{RESULTS}

\section{Inhibition of growth of bacterial strains by mycoendophytes}

The different endophytic fungi showed more or less important antibacterial activity against at least one bacterial strain. The diameters of the zones of inhibition measured vary from 6.00 to $15.33 \pm 3.32 \mathrm{~mm}$ in the two protocols (Tables I and II).

In the first protocol, we found that the genus Cladosporium did not have a significant inhibitory effect on the growth of different bacterial strains, which forced us to eliminate it from the next protocol. The genus Alternaria showed the best antibacterial activities. This genus showed an antibacterial power against the strain Staphylococcus aureus MU 50 mecA, on which the other mycoendophytes had no effect, with a rather large inhibition zone $(14.33 \pm 00 \mathrm{~mm})$. It also showed significant activity against the two bacterial strains Bacillus cereus ATCC 10876 and Bacillus cereus ATCC 14579, with respective zones of inhibition of $12.00 \pm 0.00 \mathrm{~mm}$ and 15.33 $\pm 3.32 \mathrm{~mm}$. The averages of the zones of inhibition decreased in the second protocol vis-à-vis these last two, when the mushroom is deposited alone, the diameters of inhibition are respectively $9.00 \pm 1.67$ and $10.00 \pm 0.00 \mathrm{~mm}$.

Statistical analysis showed a significant difference between the antibacterial activities of the four endophytic fungi but also between them and the antibiotic used. An additional test of multiple comparisons of Newman-Keuls averages was performed to classify fungi into homogeneous groups (Table III). In this test, we obtained groups according to the inhibition zone means of each fungus and the antibiotic after two incubation times 18 hours and 48 hours.

Table I: Inhibition of growth of bacterial strains by mycoendophytes in the first screening $(n=3$, mean \pm standard deviation).

\begin{tabular}{|c|c|c|c|c|c|c|c|c|c|c|}
\hline \multirow[b]{2}{*}{$\begin{array}{l}\text { Endophytic } \\
\text { Fungi }\end{array}$} & \multicolumn{10}{|c|}{ Zone of inhibition (mm) } \\
\hline & 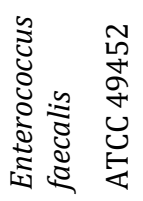 & 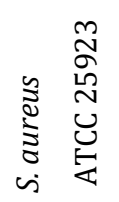 & 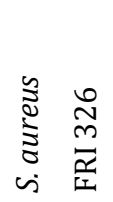 & 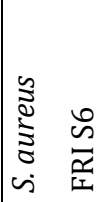 & 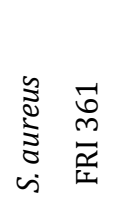 & 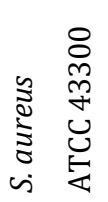 & 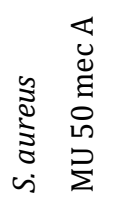 & 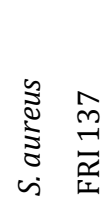 & 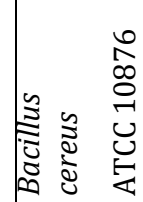 & 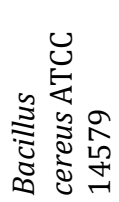 \\
\hline Cladosporium & - & - & - & - & $\begin{array}{l}7.00 \pm \\
0.00\end{array}$ & - & - & - & - & \begin{tabular}{|l|}
$10.00 \pm$ \\
0.00
\end{tabular} \\
\hline Alternaria & - & - & - & - & - & - & $\begin{array}{l}14.33 \pm \\
0.00\end{array}$ & - & $\begin{array}{l}12.00 \pm \\
0.00\end{array}$ & \begin{tabular}{|l|}
$15.33 \pm$ \\
3.32
\end{tabular} \\
\hline Aspergillus & $\begin{array}{l}8.00 \pm \\
0.00\end{array}$ & $\begin{array}{l}7.00 \pm \\
0.00\end{array}$ & - & $\begin{array}{l}6.66 \pm \\
0.00\end{array}$ & - & |- & - & $\begin{array}{l}8.00 \pm \\
0.00\end{array}$ & $\begin{array}{l}8.00 \pm \\
0.00\end{array}$ & \begin{tabular}{|l|}
$9.33 \pm$ \\
0.00
\end{tabular} \\
\hline Penicllium & - & - & - & - & $\begin{array}{l}9.33 \pm \\
1.33\end{array}$ & - & - & - & $\begin{array}{l}12.16 \pm \\
3.83\end{array}$ & \begin{tabular}{|l|}
$7.66 \pm$ \\
0.00
\end{tabular} \\
\hline ATB & $\begin{array}{l}29.10 \pm \\
0.31\end{array}$ & $\begin{array}{l}33.44 \pm \\
2.67\end{array}$ & $\begin{array}{l}34.77 \pm \\
2.43\end{array}$ & $\begin{array}{l}34.77 \\
\pm 0.15\end{array}$ & $\begin{array}{l}35.11 \pm \\
1.76\end{array}$ & $\begin{array}{l}35.44 \\
\pm 2.31\end{array}$ & $\begin{array}{l}32.32 \pm \\
0.46\end{array}$ & $\begin{array}{l}35.21 \pm \\
0.78\end{array}$ & $\begin{array}{l}32.88 \pm \\
4.56\end{array}$ & $\begin{array}{l}38.66 \pm \\
2.67\end{array}$ \\
\hline
\end{tabular}


Table II: Inhibition of growth of bacterial strains by mycoendophytes in the second screening $(\mathrm{n}=3$, mean \pm standard deviation).

\begin{tabular}{|c|c|c|c|c|c|}
\hline \multirow{2}{*}{$\begin{array}{c}\text { Endophytic } \\
\text { Fungi }\end{array}$} & $\begin{array}{c}\text { Enterococcus faecalis } \\
\text { ATCC } 49452\end{array}$ & $\begin{array}{c}\text { S. aureus } \\
\text { FRI S6 }\end{array}$ & $\begin{array}{c}\text { S. aureus } \\
\text { FRI } 361\end{array}$ & Bacillus cereus ATCC 10876 & Bacillus cereus ATCC 14579 \\
\hline Alternaria & $14.00 \pm 0.81$ & $9.66 \pm 1.24$ & $8.66 \pm 0.46$ & $9.00 \pm 1.63$ & $10.00 \pm 0.00$ \\
\hline Aspergillus & $10.66 \pm 1.24$ & $10.00 \pm 1.81$ & - & $8.66 \pm 0.46$ & $7.00 \pm 0.00$ \\
\hline Penicillium & - & - & $9.00 \pm 0.00$ & $8.00 \pm 0.81$ & $7.66 \pm 0.46$ \\
\hline ATB & $30.66 \pm 1.70$ & $37.33 \pm 0.46$ & $32.00 \pm 0.81$ & $26.00 \pm 0.00$ & $34.33 \pm 0.46$ \\
\hline
\end{tabular}

Table III: Comparison of means of zones of inhibition of mycoendophytes and the antibiotic and their effects on the growth of bacterial strains.

\begin{tabular}{|c|c|c|c|c|c|c|c|c|c|c|}
\hline \multirow[b]{2}{*}{$\begin{array}{c}\text { Endophytic } \\
\text { Fungi }\end{array}$} & \multicolumn{10}{|c|}{ Zone of inhibition (mm) } \\
\hline & 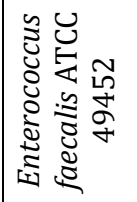 & 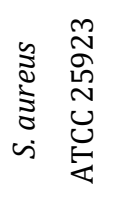 & 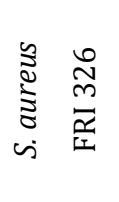 & 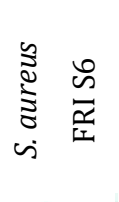 & 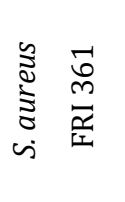 & 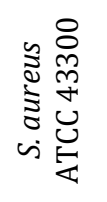 & 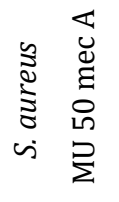 & 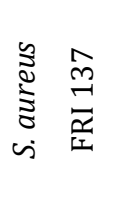 & 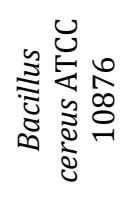 & 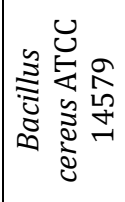 \\
\hline $\begin{array}{c}\text { Cladosporium } \\
18\end{array}$ & $\begin{array}{c}0.00 \pm \\
0.00 \mathrm{~A}\end{array}$ & $\begin{array}{l}0.00 \pm \\
0.00 \mathrm{~A}\end{array}$ & $\begin{array}{l}0.00 \pm \\
0.00 \mathrm{~A}\end{array}$ & $\begin{array}{l}0.00 \pm \\
0.00 \mathrm{~A}\end{array}$ & $\begin{array}{l}0.00 \pm \\
0.00 \mathrm{~A}\end{array}$ & $\begin{array}{l}0.00 \pm \\
0.00 \mathrm{~A}\end{array}$ & $\begin{array}{l}0.00 \pm \\
0.00 \mathrm{~A}\end{array}$ & $\begin{array}{l}0.00 \pm \\
0.00 \mathrm{~A}\end{array}$ & $\begin{array}{l}0.00 \pm \\
0.00 \mathrm{~A}\end{array}$ & $\begin{array}{l}0.00 \pm \\
0.00 \mathrm{~A}\end{array}$ \\
\hline $\begin{array}{c}\text { Cladosporium } \\
48\end{array}$ & $\begin{array}{l}0.00 \pm \\
0.00 \mathrm{~A}\end{array}$ & $\begin{array}{l}0.00 \pm \\
0.00 \mathrm{~A}\end{array}$ & $\begin{array}{l}0.00 \pm \\
0.00 \mathrm{~A}\end{array}$ & $\begin{array}{l}0.00 \pm \\
0.00 \mathrm{~A}\end{array}$ & $\begin{array}{l}0.00 \pm \\
0.00 \mathrm{~A}\end{array}$ & $\begin{array}{l}0.00 \pm \\
0.00 \mathrm{~A}\end{array}$ & $\begin{array}{l}0.00 \pm \\
0.00 \mathrm{~A}\end{array}$ & $\begin{array}{l}0.00 \pm \\
0.00 \mathrm{~A}\end{array}$ & $\begin{array}{l}0.00 \pm \\
0.00 \mathrm{~A}\end{array}$ & $\begin{array}{l}0.00 \pm \\
0.00 \mathrm{~A}\end{array}$ \\
\hline Alternaria 18 & $\begin{array}{c}11.60 \pm \\
0.00 \mathrm{~B}\end{array}$ & $\begin{array}{l}0.00 \pm \\
0.00 \mathrm{~A}\end{array}$ & $\begin{array}{l}0.00 \pm \\
0.00 \mathrm{~A}\end{array}$ & $\begin{array}{c}9.67 \pm 0 . \\
00 \mathrm{~B}\end{array}$ & $\begin{array}{c}8.67 \pm 0 . \\
00 \mathrm{~B}\end{array}$ & $\begin{array}{l}0.00 \pm \\
0.00 \mathrm{~A}\end{array}$ & $\begin{array}{l}0.00 \pm \\
0.00 \mathrm{~A}\end{array}$ & $\begin{array}{l}0.00 \pm \\
0.00 \mathrm{~A}\end{array}$ & $\begin{array}{l}9.00 \pm \\
0.00 \mathrm{~A}\end{array}$ & $\begin{array}{c}12.00 \pm \\
0.00 \mathrm{~B}\end{array}$ \\
\hline Alternaria 48 & $\begin{array}{c}14.00 \pm \\
0.00 \mathrm{~B}\end{array}$ & $\begin{array}{l}0.00 \pm \\
0.00 \mathrm{~A}\end{array}$ & $\begin{array}{l}0.00 \pm \\
0.00 \mathrm{~A}\end{array}$ & $\begin{array}{c}10.67 \pm \\
0.00 \mathrm{~B}\end{array}$ & $\begin{array}{c}10.00 \pm 0 \\
.00 \mathrm{~B}\end{array}$ & $\begin{array}{l}0.00 \pm \\
0.00 \mathrm{~A}\end{array}$ & $\begin{array}{l}0.00 \pm \\
0.00 \mathrm{~A}\end{array}$ & $\begin{array}{l}0.00 \pm \\
0.00 \mathrm{~A}\end{array}$ & $\begin{array}{l}9.00 \pm \\
0.00 \mathrm{~A}\end{array}$ & $\begin{array}{c}15.00 \pm \\
0.00 \mathrm{~B}\end{array}$ \\
\hline Aspergillus 18 & $\begin{array}{l}8.67 \pm \\
0.00 \mathrm{~A}\end{array}$ & $\begin{array}{l}7.00 \pm \\
0.00 \mathrm{~A}\end{array}$ & $\begin{array}{l}0.00 \pm \\
0.00 \mathrm{~A}\end{array}$ & $\begin{array}{c}10.00 \pm \\
0.00 \mathrm{~B}\end{array}$ & $\begin{array}{l}0.00 \pm \\
0.00 \mathrm{~A}\end{array}$ & $\begin{array}{l}0.00 \pm \\
0.00 \mathrm{~A}\end{array}$ & $\begin{array}{l}0.00 \pm \\
0.00 \mathrm{~A}\end{array}$ & $\begin{array}{l}0.00 \pm \\
0.00 \mathrm{~A}\end{array}$ & $\begin{array}{l}8.67 \pm \\
0.00 \mathrm{~A}\end{array}$ & $\begin{array}{l}7.00 \pm \\
0.00 \mathrm{~A}\end{array}$ \\
\hline Aspergillus 48 & $\begin{array}{c}8.67 \pm 0 . \\
00 \mathrm{~A}\end{array}$ & $\begin{array}{l}7.00 \pm \\
0.00 \mathrm{~A}\end{array}$ & $\begin{array}{l}0.00 \pm \\
0.00 \mathrm{~A}\end{array}$ & $\begin{array}{c}10.00 \pm \\
0.00 \mathrm{~B}\end{array}$ & $\begin{array}{l}0.00 \pm \\
0.00 \mathrm{~A}\end{array}$ & $\begin{array}{l}0.00 \pm \\
0.00 \mathrm{~A}\end{array}$ & $\begin{array}{l}0.00 \pm \\
0.00 \mathrm{~A}\end{array}$ & $\begin{array}{l}0.00 \pm \\
0.00 \mathrm{~A}\end{array}$ & $\begin{array}{l}9.67 \pm \\
0.00 \mathrm{~A}\end{array}$ & $\begin{array}{l}7.00 \pm \\
0.00 \mathrm{~A}\end{array}$ \\
\hline Penicllium 18 & $\begin{array}{l}0.00 \pm \\
0.00 \mathrm{~A}\end{array}$ & $\begin{array}{l}0.00 \pm \\
0.00 \mathrm{~A}\end{array}$ & $\begin{array}{l}0.00 \pm \\
0.00 \mathrm{~A}\end{array}$ & $\begin{array}{l}0.00 \pm \\
0.00 \mathrm{~A}\end{array}$ & $\begin{array}{c}10.66 \pm 0 \\
.00 \mathrm{~A}\end{array}$ & $\begin{array}{l}0.00 \pm \\
0.00 \mathrm{~A}\end{array}$ & $\begin{array}{l}0.00 \pm \\
0.00 \mathrm{~A}\end{array}$ & $\begin{array}{l}0.00 \pm \\
0.00 \mathrm{~A}\end{array}$ & $\begin{array}{l}8.00 \pm \\
0.00 \mathrm{~A}\end{array}$ & $\begin{array}{l}7.67 \pm \\
0.00 \mathrm{~A}\end{array}$ \\
\hline Penicillium 48 & $\begin{array}{l}0.00 \pm \\
0.00 \mathrm{~A}\end{array}$ & $\begin{array}{l}0.00 \pm \\
0.00 \mathrm{~A}\end{array}$ & $\begin{array}{l}0.00 \pm \\
0.00 \mathrm{~A}\end{array}$ & $\begin{array}{l}0.00 \pm \\
0.00 \mathrm{~A}\end{array}$ & $\begin{array}{c}10.66 \pm 0 \\
.00 \mathrm{~A}\end{array}$ & $\begin{array}{l}0.00 \pm \\
0.00 \mathrm{~A}\end{array}$ & $\begin{array}{l}0.00 \pm \\
0.00 \mathrm{~A}\end{array}$ & $\begin{array}{l}0.00 \pm \\
0.00 \mathrm{~A}\end{array}$ & $\begin{array}{l}8.00 \pm \\
0.00 \mathrm{~A}\end{array}$ & $\begin{array}{l}8.00 \pm \\
0.00 \mathrm{~A}\end{array}$ \\
\hline АТВ 18 & $\begin{array}{c}29.11 \pm 0 \\
.00 \mathrm{C}\end{array}$ & $\begin{array}{c}33.44 \pm \\
0.00 \mathrm{~B}\end{array}$ & $\begin{array}{c}34.77 \\
\pm 0.00 \mathrm{~B}\end{array}$ & $\begin{array}{c}34.77 \pm \\
2.43 \mathrm{C}\end{array}$ & $\begin{array}{c}35.11 \pm 1 \\
.76 \mathrm{C}\end{array}$ & $\begin{array}{c}35.44 \pm \\
2.31 \mathrm{~B}\end{array}$ & $\begin{array}{c}32.33 \pm \\
0.46 \mathrm{~B}\end{array}$ & $\begin{array}{c}35.22 \pm \\
0.78 \mathrm{~B}\end{array}$ & $\begin{array}{c}32.89 \pm \\
4.56 \mathrm{~B}\end{array}$ & $\begin{array}{c}34.33 \pm \\
0.46 \mathrm{C}\end{array}$ \\
\hline ATB 48 & $\begin{array}{c}29.11 \pm \\
0.31 \mathrm{C}\end{array}$ & $\begin{array}{c}33.44 \pm \\
2.67 \mathrm{~B}\end{array}$ & $\begin{array}{c}34.77 \pm \\
0.00 \mathrm{~B}\end{array}$ & $\begin{array}{c}34.77 \pm \\
2.43 \mathrm{C}\end{array}$ & $\begin{array}{c}35.11 \pm 1 \\
.76 \mathrm{C}\end{array}$ & $\begin{array}{c}35.44 \pm \\
2.31 \mathrm{~B}\end{array}$ & $\begin{array}{c}32.33 \pm \\
0.46 \mathrm{~B}\end{array}$ & $\begin{array}{c}35.22 \pm \\
0.78 \mathrm{~B}\end{array}$ & $\begin{array}{c}32.89 \pm \\
4.56 \mathrm{~B}\end{array}$ & $\begin{array}{c}34.33 \pm \\
0.46 \mathrm{C}\end{array}$ \\
\hline
\end{tabular}

\section{DISCUSSION}

All fungi have antibacterial activity against both B. cereus strains, the latter being the most sensitive of the bacteria used. On the other hand, no mycoendophyte showed any activity against the methicillin-resistant strain Staphylococcus aureus ATCC 43300 (MRSA, methicillinresistant Staphylococcus aureus), while the mycoendophyte of the Alternaria genus had an antibacterial effect against another MRSA (Staphylococcus aureus MU50 mecA).

In general, mycoendophytes excrete bioactive secondary metabolites in their culture media (Gimenez et al., 2007). For example, 3-nitropopionic acid, excreted by certain endophytic fungi, exhibits significant antimycobacterial activity (Chomcheon et al., 2005).

Other authors have also shown that there is a correlation between the simultaneous presence of endophytic fungi together and their activities vis-à-vis bacterial strains. An important antibacterial effect given by the Alternaria genus has been observed. Indeed, Arivudainambi et al. (2014) reported that Alternaria spp. Endophytes exhibit a variety of bioactive metabolites, such as phytotoxins, cytotoxins and antimicrobial compounds. They produce alkaloids such as altersetine, which shows antibacterial activity against different pathogenic Gram-positive bacteria (Hellwig et al., 2002). 


\section{Ouzid et al}

Our results showed that mycoendophytes react differently to bacterial strains, depending on whether they are present simultaneously or separately in the same petri dish, depending on the behavior and resistance of the bacterial strain. The fact that the averages of the zones of inhibition of endophytic fungi have slightly increased during the second protocol with respect to certain bacterial strains can be explained by the fact that fungi can hinder mutually the expression of their bioactive secondary metabolites when they are in the same medium due to the existence of allelopathic interactions between these endophytic fungi. These results are consistent with those of Tabuc (2007), where the simultaneous presence of several species of mycoendophytes in the same medium leads to a decrease in the production of mycotoxins by each of these and therefore a decrease in antibacterial power.

By comparing the activity of Alternaria in the two protocols, we found that the zones of inhibition are higher with respect to the two strains of Bacillus cereus in the first protocol, when it is with the other mycoendophytes in the same box. This can be explained by the possible synergies and interactions that may exist between certain fungi and that may have amplified their antibacterial power. The latter have expressed themselves better and have reacted positively against these bacterial strains. On the other hand, the genus Alternaria did not react in the first protocol to certain strains namely Enterococcus faecalis (ATCC 49452), Staphylococcus aureus (FRI S6) and Staphylococcus aureus (FRI 361). On the other hand, he spoke better in the second when he was alone against them. This may be related to the effects of metabolites excreted by different mycoendophytes, which interfered with each other's activities and prevented the expression of bioactive metabolites of the genus Alternaria. We can also think that the sensitivity of bacterial strains to the bioactive metabolites of mycoendophytes can change according to the simultaneous presence of these.

In contrast, the four endophytic fungi showed no zone of inhibition on S. aureus ATCC 43300, S. aureus FRI 326 bacterial strains. The $S$. aureus MU 50 mecA strain was susceptible only to the Alternaria genus. with an area of $14.00 \pm 0.0 \mathrm{~mm}$. Similarly for $S$. aureus FRI 137 , which reacted only against the genus Aspergillus, with a weak zone of inhibition $(8.00 \pm 0.00 \mathrm{~mm})$. Which led us not to use these strains in the second manipulation. By comparing the activity of Alternaria in the two protocols, we found that the zones of inhibition are higher with respect to the two strains of Bacillus cereus in the first protocol, when it is with the other mycoendophytes in the same box. This can be explained by the possible synergies and interactions that may exist between certain fungi and that may have amplified their antibacterial power. The latter have expressed themselves better and have reacted positively against these bacterial strains. This may be related to the effects of metabolites excreted by different mycoendophytes, which interfered with each other's activities and prevented the expression of bioactive metabolites of the genus Alternaria. We can also think that the susceptibility of bacterial strains to the bioactive metabolites of mycoendophytes and their concentrations can change according to the simultaneous presence of these and the antibiotic.

In contrast, the four endophytic fungi showed no zone of inhibition on $S$. aureus ATCC 43300, S. aureus FRI 326 bacterial strains. The $S$. aureus MU 50 mecA strain was susceptible only to the Alternaria genus with an area of $14.00 \pm 0.0 \mathrm{~mm}$. Likewise for the S. aureus FRI 137 strain, which had reacted only with respect to the genus Aspergillus, with a weak zone of inhibition $(8.00 \pm 0.00 \mathrm{~mm})$.
Journal of Drug Delivery \& Therapeutics. 2020; 10(3-s):47-51

The statistical analysis revealed 3 distinguish groups. The antibacterial behaviour of endophytic fungi and the antibiotic with respect to $S$. aureus ATCC 25923 shows the formation of two groups A and B. All endophytic fungi belong to group A with zero or very low means $(0.00 \pm 0.00 \mathrm{~mm}$ and $8.67 \pm 0.00 \mathrm{~mm})$. Group B is represented by the antibiotic (18 and 48) with an average that varies between $32.33 \pm 0.00 \mathrm{~mm}$ and $35.44 \pm 0.00 \mathrm{~mm}$. The same applies to the antibacterial behaviour of the fungi and the antibiotic with respect to $S$. aureus FRI 326, S. aureus ATCC 43300, S. aureus MU 50 mec A, S. aureus FRI 137 and Bacillus cereus ATCC 10876. Furthermore, the antibacterial behaviour of these fungi and the antibiotic towards Enterococcus feacalis ATCC 49452 S. aureus FRI S6, S. aureus FRI 361 and Bacillus cereus ATCC 14579 indicates the formation of three groups A, B and C. All endophytic fungi belong to Group A with zero or very low means. Group B is represented by the fungi which have created an inhibition zone which varies between $8.67 \pm 0.00$ and $15 \pm 0.00$. Group C is represented by the antibiotic (18 and 48 ) with an average that varies between $29.11 \pm 0.00 \mathrm{~mm}$ and $35.11 \pm 0.00 \mathrm{~mm}$.

\section{CONCLUSION}

The endophytic fungi showed a more or less important antibiotic effect, depending on the bacterial strain and conditions. The results obtained show that among the endophytic fungi studied, the genus Alternaria is one that has shown a broad spectrum of activity with respect to the bacterial strains used. Thus, it exhibited significant antibacterial activity on Gram-positive bacteria: Enterococcus faecalis ATCC 49452, Bacillus cereus ATCC10876, Bacillus cereus ATCC 14579, Staphylococcus aureus FRI 361, Staphylococcus aureus FRI S6 and was the only one to have significant against Staphylococcus aureus MU 50 mecA. Strains of Bacillus cereus were the most sensitive, so all the fungi tested reacted to it, as well as Enterococcus faecalis ATCC 49452. It also appears that the presence of mycoendophytes together or separately against each bacterial strain influences their activities and their ability to produce antibacterial compounds, either positively or negatively. The incubation time is also to be taken into consideration. An understanding of the synergies and interactions that may exist between endophytic fungi and their ability to coexist together in the same plant is necessary, in order to understand the mechanism that allowed mycoendophytes to colonize a plant known for its toxicity (Peganum harmala), to synthesize secondary metabolites and to establish interactions with this plant.

\section{ACKNOWLEDGMENTS}

The Algerian Ministry of Higher Education and Scientific Research provides financial support for this research.

\section{CONFLICT OF INTEREST}

All authors declare no have conflict of interest

\section{REFERENCES}

1. Akbary $P$, Fereidouni $M S$ and Akhlaghi $M$. In vitro antibacterial activity of Peganum harmala (L) extract to some fish pathogenic bacteria. Iranian Journal of Aquatic Animal Health, 2014; 1(1):7-16.

2. Arivudainambi US, Anantha Koteswararao E, Kotamraju S, Karunakaran $\mathrm{C}$ and Aajendran, A. Antibacterial effect of an extract of the endophytic fungus Alternaria alternata and its cytotoxic activity on MCF-7 and MDA MB-231 tumour cell lines. Biological Lett,2014; 51(1):7-17.

3. Arnold AE, Maynard Z and Gilbert GS. Fungal endophytes in dicotyledonous neotropical trees: patterns of abundance and diversity. Mycological Research, 2001; 105 (12):1502-1520.

4. Arnold AE, Mejía LC, Kyllo D, Rojas EI, Maynard Z, Robbins $\mathrm{N}$ and Herre EA. Fungal endophytes limit pathogen damage in 


\section{Ouzid et al}

a tropical tree. The National Academy of Sciences, 2003; 100(26):15649-15654.

5. Chomcheon P, Wiyakrutta S, Sriubolmas N, Ngamrojanavanich N, Isarangkul D and Kittakoop P. 3-Nitropropionic acid (3NPA), a potent antimycobacterial agent from endophytic fungi: is 3-NPA in some plants produced by endophytes? Journal of Natural Products, 2005; 68(7):1103-1105.

6. Darabpour E, Bavi AP, Motamedi $\mathrm{H}$ and Nejad SMS. Antibacterial activity of different parts of Peganum harmala L. Growing in Iran against Multi-Drug Resistant Bacteria. EXCLI Journal, 2011; 25(10):252-263.

7. Devaraju R and Satish S. Endophytic Mycoflora of Mirabilis jalapa L. and Studies on Antimicrobial Activity of its Endophytic Fusarium sp. Asian Journal of Experimental Biological Sciences, 2011 ; 2(1):75-79.

8. Ellouz, 0. Diversité des champignons endophytes mycorhiziens et de classe II chez le pois chiche, et influence du génotype de la plante. Thèse de Doctorat en Sciences, Université de Montréal, Canada, 2011; 132 pp.

9. Gimenez C, Cabrera R, Reina M and González-Coloma A Bentham Science Publishers Ltd. Fungal Endophytes and their Role in Plant Protection.Current Organic Chemistry, 2007; 11(8):707-720.

10. Hellwig V, Grothe T, Mayer-Bartschmid A, Endermann R, Geschke FU, Henkel $\mathrm{T}$ and Stadler M. Altersetin, a new antibiotic from cultures of endophytic Alternaria spp. Taxonomy, fermentation, isolation, structure elucidation and biological activities. Journal of Antibiotics, 2002; 55:881-892.

11. Javadian F, Saeidi S and Jahani S.Antimicrobial Activity of Peganum harmala and Heracleum persicum Against Acinetobacter baumannii. International Journal of Infection, 2016; 3(1):e33554.

12. Kaul S, Gupta S, Ahmed M and Dhar MK. Endophytic fungi from medicinal plants: a treasure hunts for bioactive metabolites. Phytochemistry Reviews, 2012; 11(4):487-505.
Journal of Drug Delivery \& Therapeutics. 2020; 10(3-s):47-51

13. Mandeel Q, Al-Laith A and Mohsen L. Survey of fusarium species in an arid environment of Bahrain. V. Antimicrobial activity of some local and International fusarium species. Pharmaceutical Biology, 1998; 37(3):181-187.

14. Nakamura CV, Ueda-Nakamura T, Bando E, Negrão Melo AF, Cortez DAG and Dias Filho BP. Antibacterial Activity of Ocimum gratissimum L. Essential Oil. Memorios do Instituto Oswaldo Cruz, 1999; 94(5):675-678.

15. Niroumand MC, Farzaei MH and Amin G. Medicinal properties of Peganum harmala L. in traditional Iranian medicine and modern phytotherapy: a review. Journal of Traditional Chinese Medicine, 2015; 35(1):104-109.

16. Schulz B, Boyle C, Draeger S, Rommert AK and Krohn K. Endophytic fungi: a source of novel biologically activesecondary metabolites. The British Mycological Society, Mycological Research, 2002; 106 (9):996-1004.

17. Schulz B, Boyle C and Sieber TN. What are Endophytes?, Microbial Root Endophytes, Soil Biology, 2006; 9(1):1-13.

18. Strobel G and Daisy B. Bioprospecting for Microbial Endophytes and Their Natural Products. Microbiology and Molecular Biology Reviews, 2002; 67(4):491-502.

19. Tabuc C. Flore fongique de différents substrats et conditions optimales de production des mycotoxines. Thèse de Doctorat en Sciences. INPT de Toulouse et de l'Université de Bucarest, France, $2007 ; 190 \mathrm{pp}$.

20. Valgas C, Machado de Souza S, Smânia EFA and Smânia JA. Screening methods to determine antibacterial activity of natural products. Brazilian Journal of Microbiology, 2007; 38(2):25-35.

21. Zhao J, Zhou L, Wang J, Shan T, Zhong L, Liu X and Gao X. Endophytic fungi for producing bioactive compounds originally from their host plants. Current Research, Technology and Education Topics in Applied Microbiology and Microbial Biotechnology A, 2010; 10:567-576. 